\title{
Clinical potential of the mTOR targets S6K1 and S6K2 in breast cancer
}

Gizeh Perez-Tenorio, Elin Karlsson, Marie Ahnström, Birgit Olsson, Birgitta Holmlund, Bo Nordenskjöld, Tommy Fornander, Lambert Skoog and Olle Stål

\section{Linköping University Post Print}

N.B.: When citing this work, cite the original article.

The original publication is available at www.springerlink.com:

Gizeh Perez-Tenorio, Elin Karlsson, Marie Ahnström, Birgit Olsson, Birgitta Holmlund, Bo Nordenskjöld, Tommy Fornander, Lambert Skoog and Olle Stål, Clinical potential of the mTOR targets S6K1 and S6K2 in breast cancer, 2011, Breast Cancer Research and Treatment, (128), 3, 713-723.

http://dx.doi.org/10.1007/s10549-010-1058-x

Copyright: Springer Science Business Media http://www.springerlink.com/

Postprint available at: Linköping University Electronic Press http://urn.kb.se/resolve?urn=urn:nbn:se:liu:diva-69784 
Clinical potential of the mTOR targets S6K1 and S6K2 in breast cancer

Gizeh Pérez-Tenorio ${ }^{1,4}$, Elin Karlsson ${ }^{1,4}$, Marie Ahnström Waltersson ${ }^{1}$, Birgit Olsson ${ }^{1}$, Birgitta Holmlund $^{1}$, Bo Nordenskjöld ${ }^{1}$, Tommy Fornander ${ }^{2}$, Lambert Skoog $^{3}$ and Olle Stål ${ }^{1}$

\section{Authors' affiliations:}

${ }^{1}$ Department of Clinical and Experimental Medicine, Division of Oncology, Faculty of Health Sciences, Linköping University, Linköping, Sweden,

${ }^{2}$ Department of Oncology, Karolinska University Hospital, Stockholm, Sweden

${ }^{3}$ Department of Pathology and Cytology, Karolinska University Hospital, Stockholm, Sweden

${ }^{4}$ contributed equally

\section{Corresponding author:}

Olle Stål, Department of Clinical and Experimental Medicine, Division of Oncology, Faculty of Health Sciences, Linköping University, SE-581 85 Linköping, Sweden. Phone: +4613 223491; Fax: +46 13 223090; e-mail: olle.stal@liu.se. 


\begin{abstract}
Aim: The Mammalian Target of Rapamycin (mTOR) and its substrates S6K1 and S6K2 regulate cell growth, proliferation and metabolism through translational control. RPS6KB1 (S6K1) and RPS6KB2 (S6K2) are situated in the commonly amplified 17q21-23 and 11q13 regions. $S 6 K 1$ amplification and protein overexpression have earlier been associated with a worse outcome in breast cancer, but information regarding S6K2 is scarce. The aim of this study was to evaluate the prognostic and treatment predictive relevance of $S 6 K 1 / S 6 K 2$ gene amplification, as well as S6K2 protein expression in breast cancer.
\end{abstract}

Material \& Methods: S6K1/S6K2 gene copy number was determined by real-time PCR in 207 stage II breast tumors and S6K2 protein expression was investigated by immunohistochemistry in 792 node-negative breast cancers.

Results: S6K1 amplification/gain was detected in 10.7\%/21.4\% and S6K2 amplification/gain in $4.3 \% / 21.3 \%$ of the tumors. S6K2 protein was detected in the nucleus (38\%) and cytoplasm (76\%) of the tumor cells. S6K1 amplification was significantly associated with HER2 gene amplification and protein expression. S6K2 amplification correlated significantly with high S6K2 mRNA levels, ER+ status and CCND1 amplification. $S 6 K 1$ and $S 6 K 2$ gene amplification was associated with a worse prognosis independent of HER2 and CCND1. S6K2 gain and nuclear S6K2 expression was related to an improved benefit from tamoxifen among patients with $\mathrm{ER}+$ respectively $\mathrm{ER}+/ \mathrm{PgR}+$ tumors. In the $\mathrm{ER}+/ \mathrm{PgR}-$ subgroup, nuclear $\mathrm{S} 6 \mathrm{~K} 2$ rather indicated decreased tamoxifen responsiveness. S6K1 amplification predicted reduced benefit from radiotherapy.

Conclusions: This is the first study showing that $S 6 K 2$ amplification and overexpression, like S6K1 amplification, have prognostic and treatment predictive significance in breast cancer.

Keywords: mTOR, S6 kinase, 17q21-23, 11q13, gene amplification, tamoxifen response 


\section{Introduction}

The Mammalian Target of Rapamycin (mTOR) is a serine/threonine kinase, which in response to growth factors, hormones, nutrients, hypoxia and energy (ATP) regulates cell growth, proliferation and metabolism through translational control of essential proteins [1]. mTOR is a critical effector in several cellular functions commonly deregulated in cancer, and multiple alterations resulting in overstimulation of the pathway have been described [2]. Two major regulators of mTOR function, the RAS/MAPK and PI3K/AKT signaling pathways, are constitutively activated in many cancers. Mutations in the PIK3CA gene (encoding the p110 $\alpha$ subunit of the PI3K), PTEN loss and aberrant activation or expression of AKT are some of these alterations found in breast cancer [3-5]. Cross-talk between estrogen receptor (ER) signaling and the AKT/mTOR pathway is one suggested mechanism behind endocrine resistance in breast cancer [6-8] and mTOR inhibition has been shown to increase the effect of endocrine treatments in both preclinical and clinical settings [9-11]. Since multiple oncogenic cellular pathways converge on mTOR, an important prospect is a further dissection of the downstream signaling network of mTOR and to determine the clinical relevance of genetic alterations in the mTOR signaling pathway [2].

The ribosomal S6 kinases S6K1 and S6K2 are well-known mTOR substrates, involved in regulation of the translational machinery [1, 12-14]. S6K1 and S6K2 share $70 \%$ overall amino acid identity, whereas the catalytic domains have even higher sequence homology with $>83 \%$ overlapping residues. The domain structure and the several phosphorylation sites are also conserved and are found in the corresponding drosophila dS6K, indicating that the two S6K isoforms present in mammals result from gene duplication [13, 15]. Both kinases phosphorylate the $40 \mathrm{~S}$ ribosomal protein S6 and are believed to have overlapping functions; however there are also data indicating divergence in their biological activities. In contrast to $\mathrm{S} 6 \mathrm{~K} 1, \mathrm{~S} 6 \mathrm{~K} 2$ contains a proline-rich sequence, homologous to a 
sequence in the p85 subunit of PI3K, allowing interactions with SH3 domain-containing proteins [13]. Knock-out of $S 6 K 1$ in mice, as well as drosophila $d S 6 K$ has been connected to a reduction in animal body size during embryogenesis, as a result of a decrease in individual cell size $[15,16]$. In contrast, $S 6 K 2^{-/-}$mice had normal or slightly increased body size [17]. Of note however, S6K1-deficient mice showed a significant upregulation of S6K2 protein in several tissues, suggesting a compensatory mechanism, which may explain why the phenotype of size reduction was mostly overcome by adulthood [15]. Deletion of both $S 6 K 1$ and $S 6 K 2$ in mice, as well as $d S 6 K$ in drosophila has been shown semilethal, severely reducing the viability. In contrast, no difference in lethality of $S 6 K 1$ or $S 6 K 2$ deficient mice have been seen, supporting the compensatory and essential roles for the kinases in normal development $[16,17]$.

The genes RPS6KB1 (S6K1) and RPS6KB2 (S6K2) are situated in the chromosomal regions $17 q 21-23$ and $11 q 13$, which are commonly amplified in several malignancies. In breast cancer, HER2 and CCND1 may be the most well-known oncogenes in these areas, where they are found amplified in 20-30\% [18-20] and 10-15\% [21-23] of cases, respectively. S6K1 amplification [24, 25] and S6K1 protein overexpression [24-26] has earlier been associated with a worse outcome in breast cancer, but nothing has been reported about $\mathrm{S} 6 \mathrm{~K} 2$ in this context. Due to the location of $S 6 K 2$ in a chromosomal region commonly amplified in malignancies, and the high homology between S6K1 and S6K2, one may hypothesize that also S6K2 could be of clinical importance. Consequently, the aim of this study was to evaluate the possible alterations of the mTOR targets S6K1 and S6K2 in postmenopausal breast cancer. $S 6 K 1$ and $S 6 K 2$ gene copy number was determined by fast real-time PCR in 207 stage II breast tumors; whereas S6K2 protein expression was detected by immunohistochemistry in 792 node-negative breast cancers. The prognostic and treatment predictive value regarding tamoxifen and radiotherapy was explored. 


\section{Materials and methods}

In the following section the method procedures are briefly covered, and a detailed description can be found in Supplementary Methods. Study design and presentation of results are in line with the Reporting recommendations for tumor marker prognostic studies (REMARK) guidelines [27].

\section{Patients}

The patient materials used to study $S 6 K 1 / S 6 K 2$ gene amplification and S6K2 protein expression were previously reported in detail $[28,29]$. Briefly, accrual of high-risk and lowrisk postmenopausal patients started in November 1976 and ended in April 1990. The lowrisk group included patients without positive lymph nodes and a tumor diameter $\leq 30 \mathrm{~mm}$, while the high-risk group consisted of patients with either histological verified lymph node metastases or a tumor diameter $>30 \mathrm{~mm}$. Both patient cohorts were randomized to receive adjuvant tamoxifen or no endocrine treatment. Furthermore, the high-risk group was randomized to cyclophosphamide-methotrexate-5-fluorouracil (CMF) chemotherapy or radiotherapy (RT) (Fig. 1).

The $S 6 K 1 / S 6 K 2$ gene copy number analysis comprised a subset of patients from the high-risk group, from whom frozen tumor tissue was still available after hormone receptor assays and other biochemical analyses. Furthermore, all samples included were judged to contain $>50 \%$ of malignant cells $(n=207)$. From these, 34 tumors with 11q13 amplification were selected, out of which 23 were available for $\$ 6 K 2$ mRNA expression analysis. Formalinfixed and paraffin-embedded tumors from the low-risk group $(n=912)$ were used for S6K2 protein expression analysis (Fig.1).

The two subsets showed no major differences in comparison with all the postmenopausal patients in the trial in terms of tumor characteristics and treatment. Median 
follow-up times were 18 years for the low-risk patients and 11 years for the high-risk patients.

This study was approved by the local ethical committee at the Karolinska Institute.

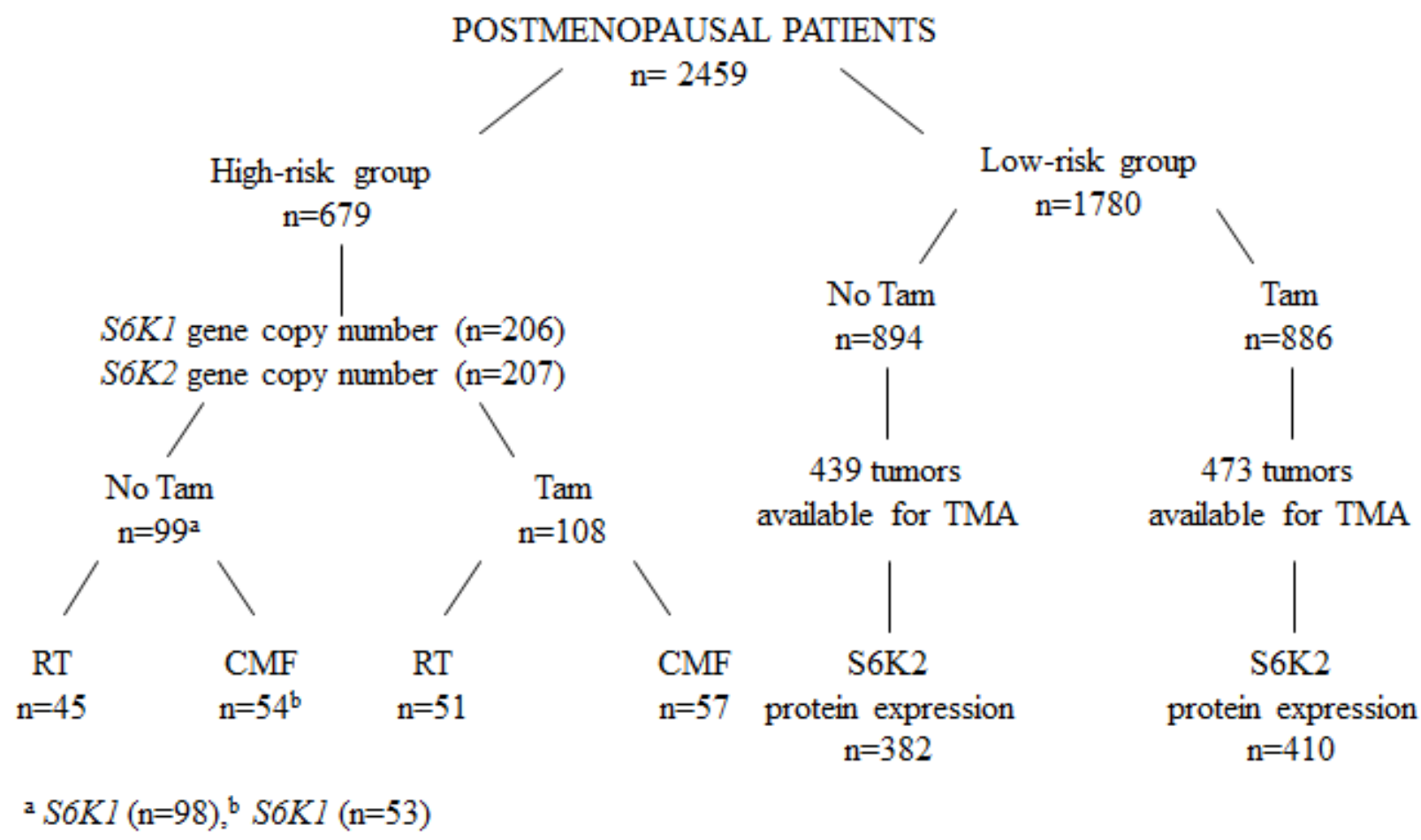

Figure 1: Representation of the patient flow through the study (TMA=tissue microarray, Tam=tamoxifen, $\mathrm{RT}$ =radiotherapy, $\mathrm{CMF}=$ cyclophosphamide-methotrexate-5-fluorouracil chemotherapy)

\section{DNA and mRNA preparation}

Extraction of genomic DNA was performed as described before [30] and DNA concentration was estimated using a NanoDrop ND-1000 Spectrophotometer (NanoDrop Technologies). For mRNA preparation, fresh frozen tumor tissue was homogenized with a microdismembrator (B Braun) and total RNA was isolated using the mirVanaTM miRNA Isolation kit (Ambion), according to manufacturer's recommendations. Purified RNA was eluted in nuclease-free water and RNasin ${ }^{\circledR}$ Ribonuclease Inhibitor (Promega) was added before storage in $-70^{\circ} \mathrm{C}$. RNA quantity and quality was assessed with an Agilent 2100 Bioanalyzer (Agilent biosystems). 
Evaluation of S6K1/S6K2 gene copy number

S6K1 and S6K2 gene copy number was determined in 206 respectively 207 available breast tumors, using quantitative real-time PCR. Details of the performance can be found in Supplementary Methods.

\section{S6K2 mRNA quantification}

S6K2 mRNA levels were measured in 23/34 available samples selected for amplification in the 11q13 area, using quantitative real-time PCR. Reverse transcription and mRNA quantitation is further described in Supplementary Methods.

\section{Immunohistochemistry and immunoblotting}

Formalin-fixed and paraffin-embedded tumors from the low-risk group ( $\mathrm{n}=912)$ were used for S6K2 protein expression analysis. Procedures for immunochemical staining of S6K2 as well as Cyclin D1, and evaluation of antibody specificity using immunoblotting are presented in detail in Supplementary Methods. Preparation of breast cancer tissue microarrays (TMA) and evaluation of ER, progesterone receptor (PgR) and HER2 protein expression have been described previously [31].

Statistical analysis

Spearman's rank order correlation was used to determine the association between S6K2 gene copy number and mRNA expression levels. The relationships between different grouped variables were assessed by the Chi-square test or Chi-square test for trend, when appropriate. The product-limit method was used for estimation of cumulative probabilities of 
recurrence-free survival (RFS) and distant recurrence-free survival (DRFS). Differences in survival between groups were tested with the log-rank test. Univariate and multivariate analysis of event rates was performed with Cox proportional hazard regression. This was also applied for interaction analysis of different factors and treatment by including the variables $\mathrm{X}$ (potential predictive factor), treatment, and the interaction variable ( $\mathrm{X} *$ treatment). All the procedures were comprised in STATISTICA, version 8.0, StatSoft, Inc. (2007). The criterion for statistical significance was $\mathrm{P}<0.05$. 


\section{Results}

S6K1 and S6K2 gene amplification

S6K1 and S6K2 gene amplification was analyzed in 206 and 207 high-risk breast tumors, respectively. Amplification ( $\geq 4$ copies) of the $S 6 K 1$ gene could be detected in 22/206 cases $(10.7 \%)$ while the $S 6 K 2$ gene was amplified in 9/207 cases (4.3\%). Gain ( $\geq 3$ copies) was observed in 44 cases for both $S 6 K 1(21.4 \%)$ and $S 6 K 2(21.3 \%)$. S6K1 amplification varied from 4 to 21 estimated copies of the gene, while $S 6 K 2$ amplification was in the range from 4 to 9 copies. Amplification of $S 6 K 1$ and $S 6 K 2$ were mutually exclusive events in the cohort (Table 1), why $S 6 K 1$ or $S 6 K 2$ amplification was detected in 31/206 cases (15\%). S6K1 gain and/or $S 6 K 2$ gain occurred in $74 / 205$ cases $(36 \%)$.

S6K1 amplification (Table 1) was significantly associated with HER2 gene amplification $(\mathrm{P}=0.025)$ and HER2 protein expression $(\mathrm{P}=0.014)$ and tended to be inversely correlated to $C C N D 1$ amplification $(\mathrm{P}=0.065)$. Also $S 6 K 1$ gain correlated significantly to HER2 amplification $(\mathrm{P}=0.007)$ and was borderline associated with high $\mathrm{S}$-phase fraction $(\mathrm{P}=0.062)$ and large tumor size $(\mathrm{P}=0.067)$. S6K2 gene copy number was significantly associated with $S 6 K 2$ mRNA expression levels (P=0.0001). Amplification of S6K2 (Table 1) correlated to positive ER status $(\mathrm{P}=0.046)$ whereas both $S 6 K 2$ amplification and $S 6 K 2$ gain correlated to CCND1 amplification $(\mathrm{p}<0.00001$ and $\mathrm{P}=0.00003)$. S6K2 gain was also significantly associated with a high $\mathrm{S}$-phase fraction $(\mathrm{P}=0.027)$. The combination variable $S 6 K 1$ or $S 6 K 2$ amplification, as well as $S 6 K 1$ and/or $S 6 K 2$ gain was inversely correlated to PIK3CA mutations $(\mathrm{P}=0.012$ and $\mathrm{P}=0.029)$, whereas the latter combination variable also correlated significantly to high S-phase fraction $(\mathrm{P}=0.016)$. 
Table 1. $S 6 K 1$ and $S 6 K 2$ gene amplification ( $\geq 4$ copies) in relation to clinicopathological factors and the PI3K/AKT pathway

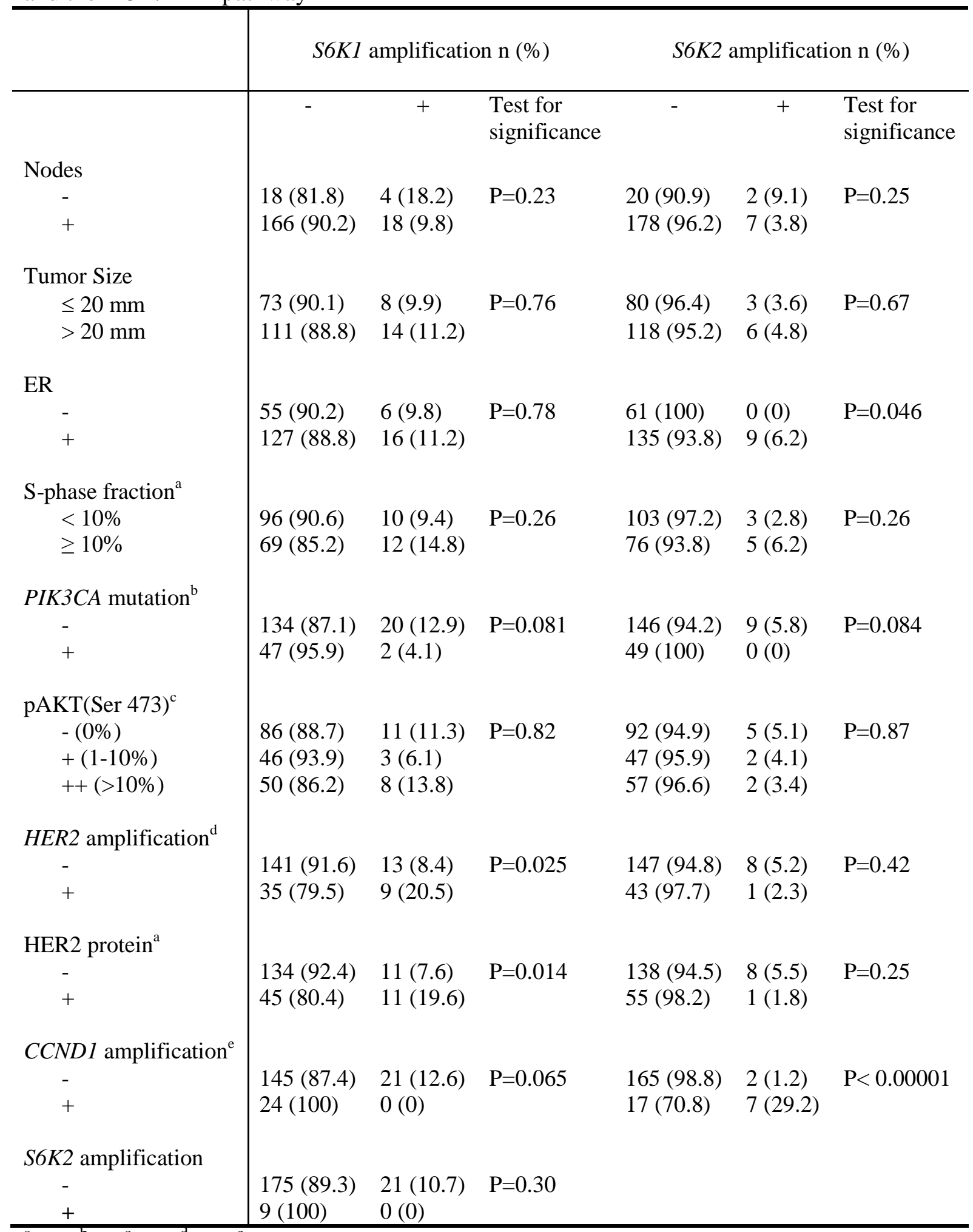

${ }^{\mathrm{a}}[50],[3],{ }^{\mathrm{c}}[51],{ }^{\mathrm{d}}[52],{ }^{\mathrm{e}}[22]$ 
S6K2 protein expression

S6K2 protein expression was analyzed with immunohistochemistry in 792/912 lowrisk breast tumors. Nuclear and cytoplasmic S6K2 were detected in $38 \%$ and $76 \%$ of the tumors respectively (Fig. 2 a-c). The S6K2 antibody was evaluated by immunoblotting in order to disregard the presence of unspecific bands or cross-reaction with the S6K1 protein (Fig. 2 d). Nuclear S6K2 was positively correlated with ER+ $(\mathrm{P}<0.00001), \mathrm{PgR}+(\mathrm{P}<$ 0.00001) status and nuclear Cyclin D1 protein expression $(\mathrm{P}<0.00001)$, whereas it was inversely correlated with HER2 protein expression $(\mathrm{P}=0.013)$. Cytoplasmic S6K2 correlated with $\mathrm{ER}+$ status $(\mathrm{P}=0.009)$ and nuclear Cyclin $\mathrm{D} 1$ protein expression $(\mathrm{P}<0.00001)$.

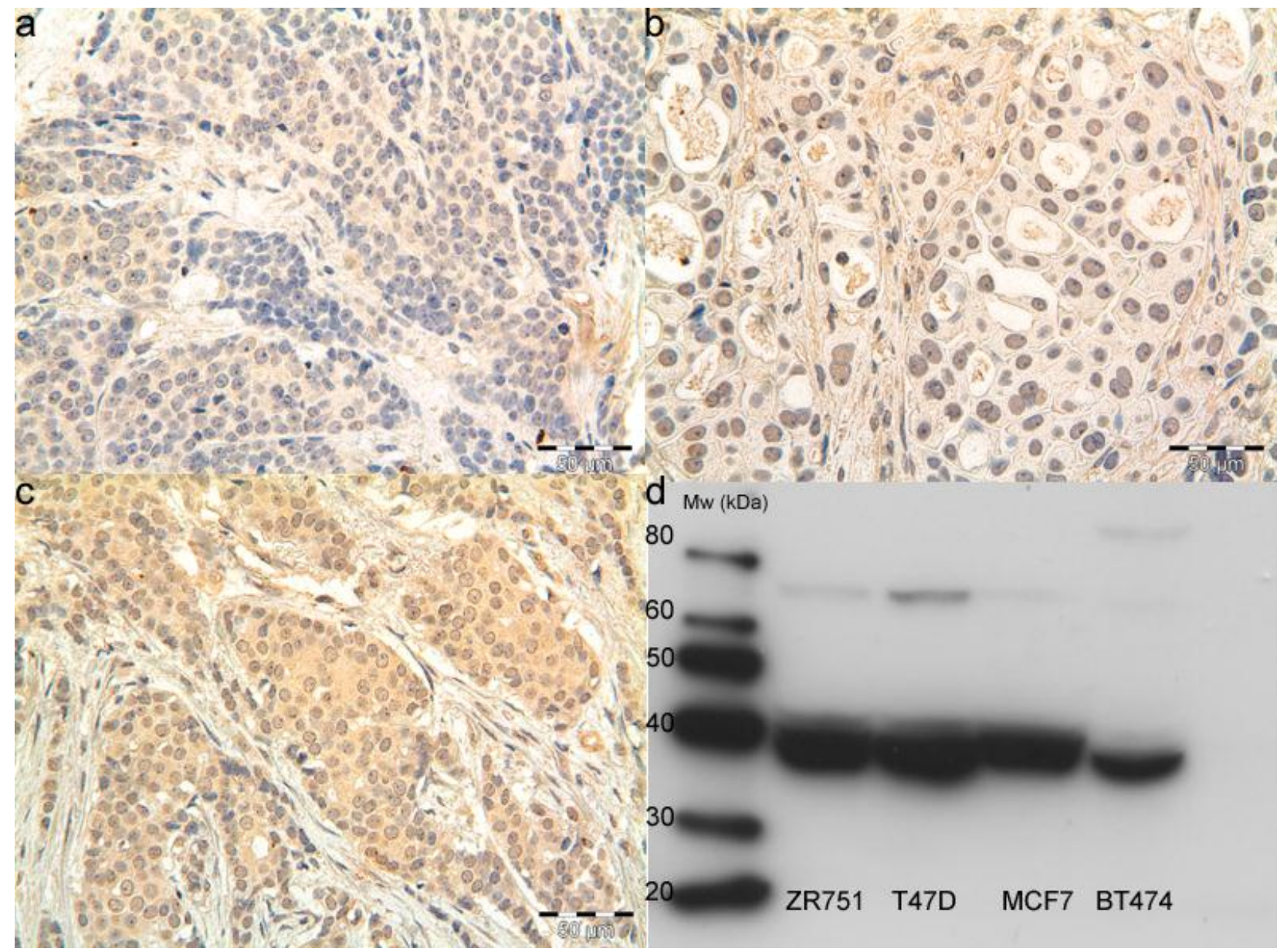

Figure 2: Immunostaining of the S6K2 protein; examples of a tumor scored negative (a), a nuclear positive tumor (b) and a nuclear and cytoplasmic positive tumor (c). The anti-S6K2 antibody was validated by immunoblotting, using lysates from ZR751, T47D, MCF7 and BT474 breast cancer cell lines $(\mathbf{d})$ 
Survival analysis

In an univariate analysis including all high-risk patients, $S 6 K 1$ gene amplification tended to confer a higher risk of developing distant metastasis $(\mathrm{HR}=1.63,95 \%$ CI, 0.92-2.85, P=0.092, Fig. 3 a) whereas $S 6 K 1$ gain was significantly associated with increased risk of distant recurrence $(\mathrm{HR}=1.62,95 \% \mathrm{CI}, 1.05-2.52, \mathrm{P}=0.031$, Fig. 3 b).

Amplification of $S 6 K 2$ significantly predicted a higher risk of distant recurrence in breast cancer $(\mathrm{HR}=2.70,95 \% \mathrm{CI}, 1.24-5.83, \mathrm{P}=0.012$, Fig. $3 \mathrm{c})$, whereas this could not be seen for $S 6 K 2$ gain $(\mathrm{HR}=1.29,95 \%$ CI, 0.83-2.01, P=0.26, Fig. $3 \mathrm{~d})$.

The combination variable $S 6 K 1$ or $S 6 K 2$ amplification was significantly associated with poor DRFS (HR=1.98, 95\% CI, 1.22-3.20, P=0.006, Fig. 3 e) and this was also true for the combination variable $S 6 K 1$ and/or $\mathrm{S} 6 K 2$ gain $(\mathrm{HR}=1.61,95 \% \mathrm{CI}, 1.09-2.37$, $\mathrm{P}=0.016$, Fig. 3 f). Among patients with ER positive tumors, the combination variables tended to have an even stronger prognostic value in terms of DRFS (S6K1 or $S 6 K 2$ amplification: $\mathrm{HR}=2.23,95 \% \mathrm{CI}, 1.29-3.88, \mathrm{P}=0.0044 ; S 6 K 1$ and/or $S 6 K 2$ gain: HR=1.90, 95\% CI, 1.18 3.05, $\mathrm{P}=0.008)$.

In a multivariate analysis, including $H E R 2$ and $C C N D 1$ amplification as well as treatment, among other common variables, $S 6 K 2$ amplification remained an independent prognostic factor of increased risk for distant recurrence, whereas $S 6 K 1$ gene amplification reached borderline significance (Table 2). The combination variables $S 6 K 1$ or $S 6 K 2$ amplification $(\mathrm{HR}=2.11,95 \% \mathrm{CI}, 1.27-3.50, \mathrm{P}=0.004)$ as well as $S 6 K 1$ and/or $S 6 K 2$ gain $(\mathrm{HR}=1.54,95 \% \mathrm{CI}, 1.00-2.38, \mathrm{P}=0.049)$ also resulted as independent prognostic factors in an analogous multivariate analysis.

In the cohort of low-risk patients, S6K2 protein expression did not show any prognostic value (data not shown). 

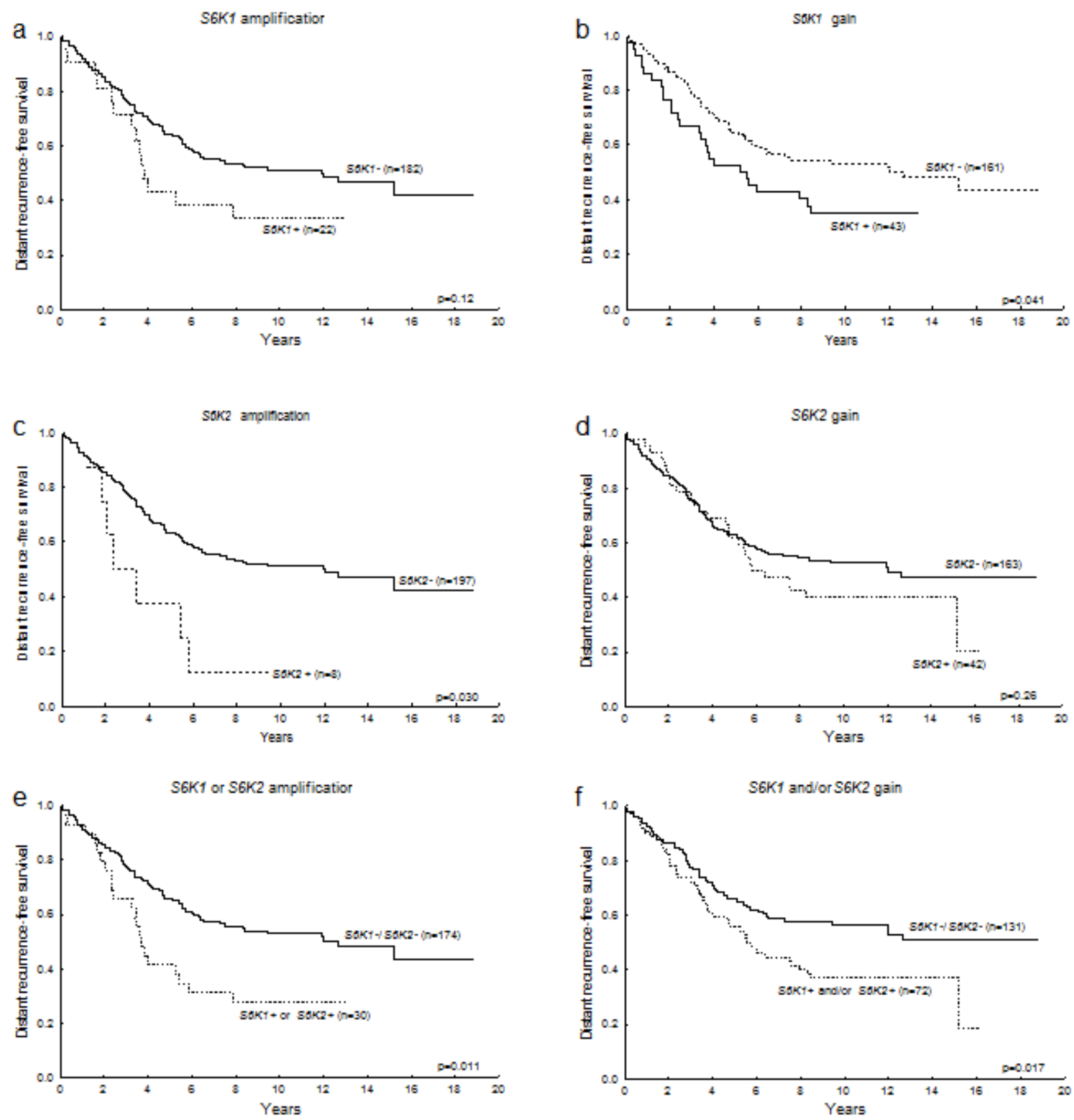

Figure 3: Distant recurrence-free survival among all high-risk patients, in relation to S6K1 amplification (a), $S 6 K 1$ gain (b), $S 6 K 2$ amplification (c), $S 6 K 2$ gain (d), the combination variables $S 6 K 1$ or $S 6 K 2$ amplification (e) and $S 6 K 1$ and/or $S 6 K 2$ gain (f). (amplification $\geq 4$ gene copies, gain $\geq 3$ gene copies) 
Table 2. Multivariate analysis of distant recurrence using Cox proportional hazard regression

\begin{tabular}{l|ll}
\hline & $\mathrm{HR}(95 \% \mathrm{CI})$ & Test for significance \\
\hline $\begin{array}{l}\text { Lymph node status } \\
\text { N+ vs. N- }\end{array}$ & $2.59(1.09-6.15)$ & $\mathrm{P}=0.032$ \\
$\begin{array}{l}\text { Tumor size } \\
>20 \mathrm{~mm} \text { vs. } \leq 20 \mathrm{~mm}\end{array}$ & $1.77(1.13-2.75)$ & $\mathrm{P}=0.012$ \\
$\begin{array}{l}\text { ER status } \\
\text { ER+ vs. ER- }\end{array}$ & $\mathrm{P}=0.39$ \\
$\begin{array}{l}\text { HER2 gene amplification } \\
\text { Amplified vs. nonamplified }\end{array}$ & $1.63(1.01-2.64)$ & $\mathrm{P}=0.045$ \\
$\begin{array}{l}\text { CCND1 gene amplification } \\
\text { Amplified vs. nonamplified }\end{array}$ & $0.95(0.46-1.99)$ & $\mathrm{P}=0.90$ \\
$\begin{array}{l}\text { Tamoxifen vs. no } \\
\text { Tamoxifen }\end{array}$ & $0.77(0.51-1.17)$ & $\mathrm{P}=0.22$ \\
$\begin{array}{l}\text { Chemotherapy vs. } \\
\text { Radiotherapy } \\
\text { S6K1 gene amplification } \\
\text { Amplified vs. nonamplified } \\
\text { S6K2 gene amplification } \\
\text { Amplified vs. nonamplified }\end{array}$ & $1.78(0.98-3.22)$ & $\mathrm{P}=0.49$ \\
\hline
\end{tabular}

\section{Treatment prediction}

As a result of the low number of cases with $S 6 K 2$ amplification, $S 6 K 2$ gain was considered in analyses of treatment prediction. The benefit from tamoxifen was evident for high-risk patients having ER positive tumors with $S 6 K 2$ gain regarding DRFS, whereas no significant tamoxifen response could be seen in the $S 6 K 2$ negative group (Fig. 4 a, b). In the low-risk group, nuclear S6K2 protein expression was associated with an increased benefit from tamoxifen among patients with $\mathrm{ER}+/ \mathrm{PgR}+$ tumors (Fig. $4 \mathrm{c}$, d). However in the $\mathrm{ER}+/ \mathrm{PgR}$ - group, nuclear S6K2 expression was rather an indicator of decreased tamoxifen responsiveness (Fig. 4 e, f). In an interaction test, $S 6 K 2$ gain had borderline significance as a 

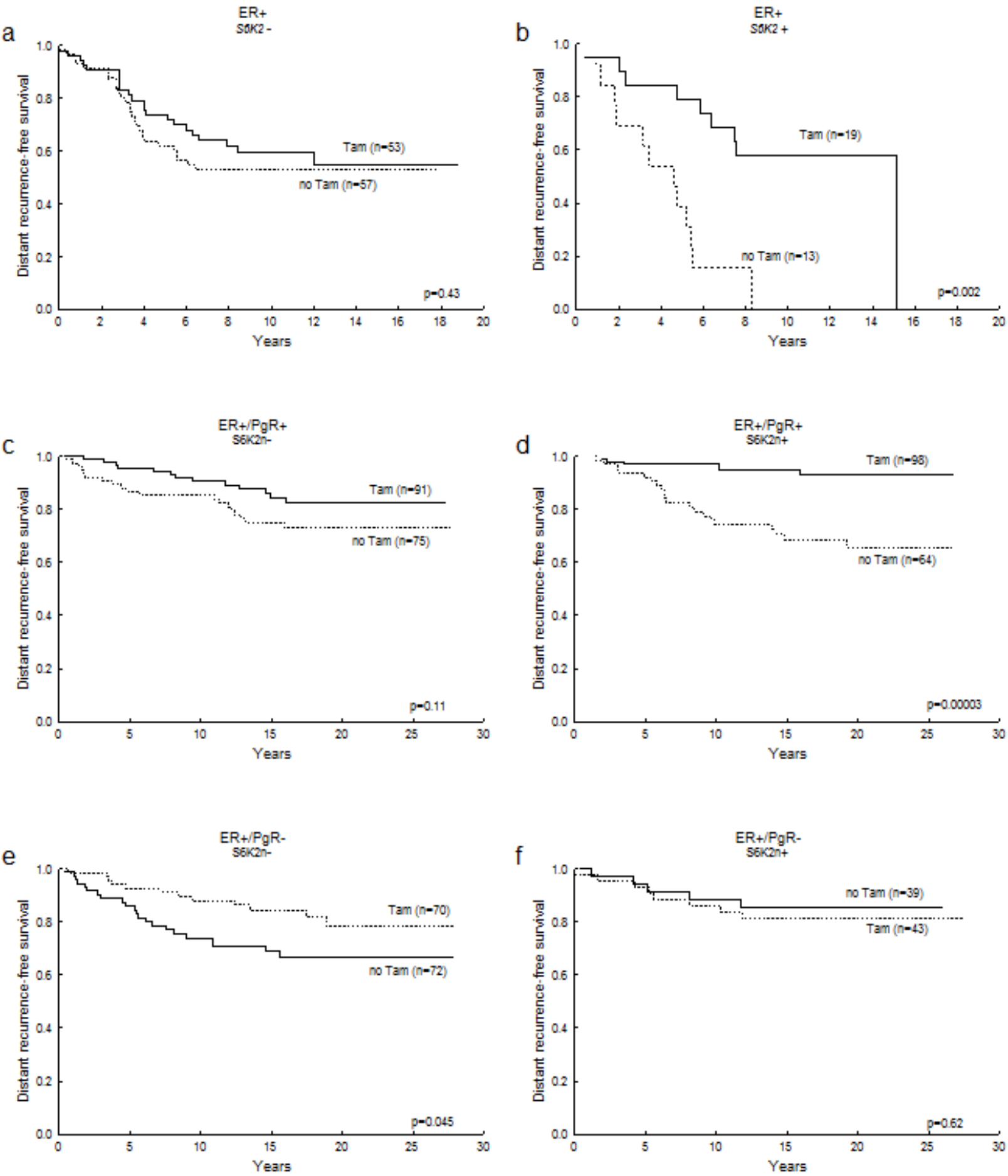

Figure 4: Distant recurrence-free survival for breast cancer patients treated with tamoxifen (Tam) vs. no tamoxifen (no Tam) in relation to S6K2 status; $S 6 K 2-$ ( $<3$ gene copies) (a), $S 6 K 2+(\geq 3$ gene copies) (b), S6K2n- (no nuclear S6K2 staining), ER+/PgR+ tumors (c), S6K2n+ (positive nuclear S6K2 staining), ER+/PgR+ tumors (d), S6K2n- (no nuclear S6K2 staining), ER+/PgRtumors (e) and S6K2n+ (positive nuclear S6K2 staining), ER+/PgR-tumors (f). (a, b: stage II tumors; c-f: node-negative breast cancers) 
predictor of increased tamoxifen efficacy, using DRFS as the end-point (Table 3) and the interaction reached significance in terms of RFS ( $\mathrm{P}=0.026$, data not shown). Also nuclear S6K2 protein expression interacted significantly with the benefit from tamoxifen among the low-risk $\mathrm{ER}+/ \mathrm{PgR}+$ patients, whereas a trend for a negative interaction between nuclear S6K2 and tamoxifen efficacy could be seen in the ER+/PgR- group (Table 4). S6K1 gene amplification alone did not show any predictive value regarding tamoxifen treatment (Table 3), however a trend was seen for the combination variable $S 6 K 1$ amplification and/or $S 6 K 2$ gain to predict increased benefit from tamoxifen (Table 3), and the test for interaction reached significance using RFS as the primary end-point ( $\mathrm{P}=0.046$, data not shown).

Table 3. Cox proportional hazard regression of distant recurrence rate for patients with stage II, ER+ tumors, treated or not with adjuvant tamoxifen, in relation to $S 6 K 1$ amplification ( $\geq 4$ gene copies), $S 6 K 2$ gain ( $\geq 3$ gene copies) and the combination variable $S 6 K 1$ amplification and/or S6K2 gain

\begin{tabular}{c|llll}
\hline & No. of patients & \multicolumn{2}{l}{ Tamoxifen vs. no tamoxifen } & $\begin{array}{l}\text { Test for } \\
\text { HR }(95 \% \text { CI })\end{array}$ \\
\hline $\begin{array}{c}\text { S6K1 amplification } \\
-\end{array}$ & 125 & $0.66(0.40-1.10)$ & $\mathrm{P}=0.11$ & \\
+ & 16 & $0.62(0.16-2.40)$ & $\mathrm{P}=0.49$ & $\mathrm{P}=0.94$ \\
S6K2 gain & & & & \\
- & 110 & $0.80(0.45-1.41)$ & $\mathrm{P}=0.44$ & \\
+ & 32 & $0.21(0.08-0.53)$ & $\mathrm{P}=0.001$ & $\mathrm{P}=0.065$ \\
$\begin{array}{c}\text { S6K1 amplification } \\
\text { and/or S6K2 gain }\end{array}$ & & & & \\
- & 96 & $0.81(0.43-1.52)$ & $\mathrm{P}=0.52$ & \\
+ & 46 & $0.34(0.26-0.74)$ & $\mathrm{P}=0.006$ & $\mathrm{P}=0.16$ \\
\hline
\end{tabular}

In terms of loco-regional control, the patients with normal $S 6 K 1$ gene copy number responded significantly better to radiotherapy compared to chemotherapy in contrast to the patients harboring tumors with S6K1 amplification (Supplementary Table 1). Genomic amplification on 17q21-23 including S6K1 and/or HER2 gene amplification, also indicated 
poor response to radiotherapy (Supplementary Fig. 1). Both 17q21-23 and S6K1 amplification interacted significantly with the benefit from radiotherapy (Supplementary Table 1). A similar trend was seen for $S 6 K 2$, where a normal copy number was associated with a significant benefit from radiotherapy compared to chemotherapy, whereas $\$ 6 K 2$ gain was not (Supplementary Table 1). Though, no significant interaction between $S 6 K 2$ or the combination variable $S 6 K 1$ amplification and/or $S 6 K 2$ gain, and radiotherapy, was evident (Supplementary Table 1).

Table 4. Cox proportional hazard regression of distant recurrence rate for patients with nodenegative breast cancers, and $\mathrm{ER}+, \mathrm{ER}+\mathrm{PgR}+$ or $\mathrm{ER}+/ \mathrm{PgR}$ - tumors, respectively, treated or not with adjuvant tamoxifen, in relation to nuclear S6K2 protein expression

\begin{tabular}{c|llll}
\hline & No. of patients & \multicolumn{1}{c}{ Tamoxifen vs. no tamoxifen } & $\begin{array}{l}\text { Test for } \\
\text { interaction }\end{array}$ \\
\hline ER+ & & & \\
S6K2n- & 337 & $0.54(0.33-0.88)$ & $\mathrm{P}=0.013$ & \\
S6K2n+ & 265 & $0.44(0.21-0.78)$ & $\mathrm{P}=0.007$ & $\mathrm{P}=0.52$ \\
& & & & \\
ER+/PgR+ & & & & \\
S6K2n- & 165 & $0.60(0.29-1.22)$ & $\mathrm{P}=0.16$ & \\
S6K2n+ & 163 & $0.17(0.07-0.42)$ & $\mathrm{P}=0.0001$ & $\mathrm{P}=0.034$ \\
& & & & \\
ER+/PgR- & & & & \\
$\quad$ S6K2n- & 142 & $0.49(0.24-1.00)$ & $\mathrm{P}=0.049$ & \\
S6K2n+ & 80 & $1.33(0.43-4.06)$ & $\mathrm{P}=0.62$ & $\mathrm{P}=0.13$ \\
\hline
\end{tabular}




\section{Discussion}

Genomic amplifications occur frequently and non-randomly in tumors and are expected to be essential for the development and progression of malignancy. In breast cancer, 17q21-23 and 11q13 are commonly amplified chromosomal regions where HER2 and CCND1 may be the most well-known oncogenes [18-23]. The present study suggests a role for $S 6 K 1$ and $S 6 K 2$ as clinically valuable in these amplicons.

This is the first study to report amplification/gain of $S 6 K 2$ and its correlation to an increased $S 6 K 2$ mRNA expression in primary breast tumors. Amplification of the homologous $56 K 1$ was detected in about $10 \%$ of the tumors, which is in agreement with earlier studies where amplification of $S 6 K 1$ also has been correlated to increased expression of the corresponding protein $[24,25,32] . S 6 K 1$ and $S 6 K 2$ amplification were mutually exclusive events in the cohort, suggesting compensatory roles as tumor driving oncogenes.

The joint value of $S 6 K 1$ and/or $S 6 K 2$ gene copy number alterations was explored and appeared to be of clinical relevance.

Amplification and gain of $S 6 K 1$ was significantly associated with HER2 gene amplification and HER2 protein overexpression. The possibility of S6K1 and HER2 coamplification has been discussed before due to their physical proximity [24]. S6K1 was identified as the first candidate oncogene in the 17q23 region [33] and $S 6 K 1$ or S6K1/HER2 amplification have been associated to a poor outcome in breast cancer [24].

S6K2 amplification and gain were strongly correlated to CCND1 amplification. The physical proximity of these two genes $(2.2 \mathrm{Mb})$ suggests that they belong to the same amplicon or to frequently coamplified cores within the 11q13 area [34]. 11q13 amplification has in several studies been connected to positive ER status in breast cancer $[35,36]$, which could also be confirmed here for amplification of $S 6 K 2$. However, the mechanisms behind a possible interaction between 11q13 and ER remain to be elucidated. 
Of note, amplification or gain of $S 6 K 1$ or $S 6 K 2$ were inversely correlated with the presence of PIK3CA mutations, indicating that deregulation of the S6 kinases may be an alternative and compensatory mechanism for PI3K/AKT stimulation in breast tumors.

S6K1 and S6K2 share structural homology although they exhibit differences in the C and $\mathrm{N}$ terminal domains [14]. The S6 kinases have earlier been observed in both cytoplasmic and nuclear compartments of malignant cells [37] where different S6K1 and 2 isoforms have been reported. S6K1 exists as p70 and p85 isoforms. Likewise, the two S6K2 isoforms p60/ $\beta \mathrm{I}$ and p54/ $\beta$ II have been found in the cytoplasm and the nucleus [38]. Since the known function of these proteins is so far coupled to phosphorylation of a ribosomal protein present in the cytoplasm, the role of the nuclear S6K1/2 is intriguing, suggesting the possibility of other substrates. S6K1 protein expression have earlier been correlated to $S 6 K 1$ gene amplification $[24,25]$ and associated with a worse outcome in breast cancer [24-26] but very little is known about S6K2 protein expression. In the present study, S6K2 protein could be detected in the nuclear and cytoplasmic compartments of breast tumor cells. In accordance with $S 6 K 2$ amplification, S6K2 protein expression also correlated to Cyclin D1 expression and ER positive status, but also to $\mathrm{PgR}$ expression, implying a functional connection at the cellular level between S6K2 and ER signaling.

The current data confirm a role for both $S 6 K 1$ and $S 6 K 2$ amplification/gain as prognostic factors in breast cancer, possibly of greatest significance in the ER-positive subgroup. $S 6 K 2$ amplification remained as an independent prognostic factor and S6K1 reached borderline significance in a multivariate analysis including HER2 and CCND1 amplification as well as treatment, among other common variables, demonstrating the individual contribution of the S6 kinases as potential oncogenes in the amplicons. The combination variables $S 6 K 1$ or $S 6 K 2$ amplification, as well as $S 6 K 1$ and/or $S 6 K 2$ gain, also remained independent prognostic factors in analogues analysis. 
Anti-estrogen treatments are corner stones in the management of ER positive breast cancer, however de novo and acquired endocrine resistance remains a substantial problem. Identifying new biomarkers for prediction of responsiveness to endocrine treatments is therefore of great importance [39]. Results from this study indicate that the S6 kinases, in particular $\mathrm{S} 6 \mathrm{~K} 2$, may be relevant in this context. Increased $S 6 K 2$ gene copy number and nuclear S6K2 expression was shown related to a better response to tamoxifen among patients with ER positive tumors. Interestingly, the ability of S6K2 to predict benefit from tamoxifen was restricted to the ER+/PgR+ subgroup among the low-risk cohort in the present study. Among patients with $\mathrm{ER}+/ \mathrm{PgR}$ - tumors, nuclear S6K2 expression was rather connected to a worse response to endocrine treatment. This allows for the speculation that ER signaling in this subgroup may be driven in a hormone-independent manner, via cross-talk to intracellular signaling pathways including mTOR/S6K. mTOR inhibitors have been shown effective in combination with endocrine therapies in both clinical and preclinical studies [9-11]. In the light of the present findings, S6K2 may have a role in predicting when this combination therapy is useful. S6K1 has earlier been implicated in the regulation of ER signaling by phosphorylating ER $\alpha$-Ser 167, leading to increased ER transcriptional activity and cell growth in vitro [40]. In addition, phosphorylation of ER $\alpha$-Ser 167 has been associated with better response to tamoxifen $[41,42]$, and a similar role for S6K2 in ER phosphorylation may be conceivable. The proline-rich motif found in S6K2 may support this speculation, since a proline rich, SH3 binding domain in certain ER coactivators have been shown essential for their function and interactions with $\mathrm{ER} \alpha[43]$.

The HER2/PI3K/AKT signaling pathway has earlier been implicated in resistance to radiation-induced apoptosis in breast tumors [44], and this can be reversed by the HER2 inhibitor trastuzumab [45]. Results from the present study reveal that $S 6 K 1$ may also be of interest in this context, in particular in connection to HER2 coamplification. A similar role 
for $S 6 K 2$ cannot be excluded, however, the impact on radiosensitivity appear to be mainly connected to the 17q21-23 amplicon. Of note, the $R A D 51 C$ gene is located about $1 \mathrm{Mb}$ from S6K1, and the RAD51 DNA repair family has in both in vivo and in vitro studies been related to a poor sensitivity of radiation-induced apoptosis [46-49].

In conclusion, this study shows for the first time that $S 6 K 2$ is amplified and overexpressed in breast tumors, which like $S 6 K 1$ amplification may have prognostic significance. Resulting data demonstrate a role for the S6 kinases in predicting response of tamoxifen as well as radiotherapy treatment, but further studies are needed to uncover underlying mechanisms. The mTOR targets S6K1 and S6K2 may possess both compensatory and non-redundant functions associated with malignancy and therefore have potential as new prognostic and predictive markers in breast cancer.

\section{Acknowledgments}

This study was supported by grants from the Swedish Cancer Foundation, Swedish Research Council and King Gustaf V Jubilee Fund.

\section{Disclosure/conflict of interest}

The authors have no conflicts of interest do disclose. 


\section{References}

1. Ma XM, Blenis J (2009) Molecular mechanisms of mTOR-mediated translational control. Nat Rev Mol Cell Biol 10: 307-318.

2. Guertin DA, Sabatini DM (2007) Defining the role of mTOR in cancer. Cancer Cell 12: 9-22.

3. Perez-Tenorio G, Alkhori L, Olsson B, Waltersson MA, Nordenskjöld B, Rutqvist LE, Skoog L, Stål O (2007) PIK3CA mutations and PTEN loss correlate with similar prognostic factors and are not mutually exclusive in breast cancer. Clin Cancer Res 13: 3577-3584.

4. Saal LH, Holm K, Maurer M, Memeo L, Su T, Wang X, Yu JS, Malmström PO, Mansukhani M, Enoksson J, Hibshoosh H, Borg Å, Parsons R (2005) PIK3CA mutations correlate with hormone receptors, node metastasis, and ERBB2, and are mutually exclusive with PTEN loss in human breast carcinoma. Cancer Res 65: 25542559.

5. Samuels Y, Wang Z, Bardelli A, Silliman N, Ptak J, Szabo S, Yan H, Gazdar A, Powell SM, Riggins GJ, Willson JK, Markowitz S, Kinzler KW, Vogelstein B, Velculescu VE (2004) High frequency of mutations of the PIK3CA gene in human cancers. Science 304: 554.

6. Bärlund M, Boulay A, Rudloff J, Ye J, Zumstein-Mecker S, O'Reilly T, Evans DB, Chen S, Lane HA (2005) Dual inhibition of mTOR and estrogen receptor signaling in vitro induces cell death in models of breast cancer. Clin Cancer Res 11: 5319-5328.

7. Kurokawa H, Arteaga CL (2003) ErbB (HER) receptors can abrogate antiestrogen action in human breast cancer by multiple signaling mechanisms. Clin Cancer Res 9: 511S-515S.

8. Schiff R, Massarweh SA, Shou J, Bharwani L, Mohsin SK, Osborne CK (2004) Crosstalk between estrogen receptor and growth factor pathways as a molecular target for overcoming endocrine resistance. Clin Cancer Res 10: 331S-336S.

9. Chan S, Scheulen ME, Johnston S, Mross K, Cardoso F, Dittrich C, Eiermann W, Hess D, Morant R, Semiglazov V, Borner M, Salzberg M, Ostapenko V, Illiger HJ, Behringer D, Bardy-Bouxin N, Boni J, Kong S, Cincotta M, Moore L (2005) Phase II study of temsirolimus (CCI-779), a novel inhibitor of mTOR, in heavily pretreated patients with locally advanced or metastatic breast cancer. J Clin Oncol 23: 53145322. Epub 2005 Jun 5313.

10. deGraffenried LA, Friedrichs WE, Russell DH, Donzis EJ, Middleton AK, Silva JM, Roth RA, Hidalgo M (2004) Inhibition of mTOR activity restores tamoxifen response in breast cancer cells with aberrant Akt Activity. Clin Cancer Res 10: 8059-8067.

11. Baselga J, Semiglazov V, van Dam P, Manikhas A, Bellet M, Mayordomo J, Campone M, Kubista E, Greil R, Bianchi G, Steinseifer J, Molloy B, Tokaji E, Gardner H, Phillips P, Stumm M, Lane HA, Dixon JM, Jonat W, Rugo HS (2009) Phase II randomized study of neoadjuvant everolimus plus letrozole compared with placebo plus letrozole in patients with estrogen receptor-positive breast cancer. J Clin Oncol 27: 2630-2637.

12. Park IH, Bachmann R, Shirazi H, Chen J (2002) Regulation of ribosomal S6 kinase 2 by mammalian target of rapamycin. J Biol Chem 277: 31423-31429.

13. Jastrzebski K, Hannan KM, Tchoubrieva EB, Hannan RD, Pearson RB (2007) Coordinate regulation of ribosome biogenesis and function by the ribosomal protein S6 kinase, a key mediator of mTOR function. Growth Factors 25: 209-226. 
14. Lee-Fruman KK, Kuo CJ, Lippincott J, Terada N, Blenis J (1999) Characterization of S6K2, a novel kinase homologous to S6K1. Oncogene 18: 5108-5114.

15. Shima H, Pende M, Chen Y, Fumagalli S, Thomas G, Kozma SC (1998) Disruption of the $\mathrm{p} 70(\mathrm{~s} 6 \mathrm{k}) / \mathrm{p} 85(\mathrm{~s} 6 \mathrm{k})$ gene reveals a small mouse phenotype and a new functional S6 kinase. Embo J 17: 6649-6659.

16. Montagne J, Stewart MJ, Stocker H, Hafen E, Kozma SC, Thomas G (1999) Drosophila S6 kinase: a regulator of cell size. Science 285: 2126-2129.

17. Pende M, Um SH, Mieulet V, Sticker M, Goss VL, Mestan J, Mueller M, Fumagalli S, Kozma SC, Thomas G (2004) S6K1(-/-)/S6K2(-/-) mice exhibit perinatal lethality and rapamycin-sensitive 5'-terminal oligopyrimidine mRNA translation and reveal a mitogen-activated protein kinase-dependent S6 kinase pathway. Mol Cell Biol 24: 3112-3124.

18. Lofts FJ, Gullick WJ (1992) c-erbB2 amplification and overexpression in human tumors. Cancer Treat Res 61: 161-179.

19. Singleton TP, Strickler JG (1992) Clinical and pathologic significance of the c-erbB-2 (HER-2/neu) oncogene. Pathol Annu 27 Pt 1: 165-190.

20. Slamon DJ, Clark GM, Wong SG, Levin WJ, Ullrich A, McGuire WL (1987) Human breast cancer: correlation of relapse and survival with amplification of the HER-2/neu oncogene. Science 235: 177-182.

21. Al-Kuraya K, Schraml P, Torhorst J, Tapia C, Zaharieva B, Novotny H, Spichtin H, Maurer R, Mirlacher M, Kochli O, Zuber M, Dieterich H, Mross F, Wilber K, Simon R, Sauter G (2004) Prognostic relevance of gene amplifications and coamplifications in breast cancer. Cancer Res 64: 8534-8540.

22. Bostner J, Ahnström Waltersson M, Fornander T, Skoog L, Nordenskjöld B, Stål O (2007) Amplification of CCND1 and PAK1 as predictors of recurrence and tamoxifen resistance in postmenopausal breast cancer. Oncogene 26: 6997-7005.

23. Jirström K, Stendahl M, Ryden L, Kronblad A, Bendahl PO, Stål O, Landberg G (2005) Adverse effect of adjuvant tamoxifen in premenopausal breast cancer with cyclin D1 gene amplification. Cancer Res 65: 8009-8016.

24. Bärlund M, Forozan F, Kononen J, Bubendorf L, Chen Y, Bittner ML, Torhorst J, Haas P, Bucher C, Sauter G, Kallioniemi OP, Kallioniemi A (2000) Detecting activation of ribosomal protein S6 kinase by complementary DNA and tissue microarray analysis. J Natl Cancer Inst 92: 1252-1259.

25. van der Hage JA, van den Broek LJ, Legrand C, Clahsen PC, Bosch CJ, RobanusMaandag EC, van de Velde CJ, van de Vijver MJ (2004) Overexpression of P70 S6 kinase protein is associated with increased risk of locoregional recurrence in nodenegative premenopausal early breast cancer patients. Br J Cancer 90: 1543-1550.

26. Noh WC, Kim YH, Kim MS, Koh JS, Kim HA, Moon NM, Paik NS (2008) Activation of the mTOR signaling pathway in breast cancer and its correlation with the clinicopathologic variables. Breast Cancer Res Treat 110: 477-483.

27. McShane LM, Altman DG, Sauerbrei W, Taube SE, Gion M, Clark GM (2006) REporting recommendations for tumor MARKer prognostic studies (REMARK). Breast Cancer Res Treat 100: 229-235.

28. Rutqvist LE, Johansson H (2006) Long-term follow-up of the Stockholm randomized trials of postoperative radiation therapy versus adjuvant chemotherapy among 'high risk' pre- and postmenopausal breast cancer patients. Acta Oncol 45: 517-527.

29. Rutqvist LE, Johansson H (2007) Long-term follow-up of the randomized Stockholm trial on adjuvant tamoxifen among postmenopausal patients with early stage breast cancer. Acta Oncol 46: 133-145. 
30. Askmalm MS, Carstensen J, Nordenskjöld B, Olsson B, Rutqvist LE, Skoog L, Stål O (2004) Mutation and accumulation of p53 related to results of adjuvant therapy of postmenopausal breast cancer patients. Acta Oncol 43: 235-244.

31. Jansson A, Delander L, Gunnarsson C, Fornander T, Skoog L, Nordenskjöld B, Stål O (2009) Ratio of 17HSD1 to 17HSD2 protein expression predicts the outcome of tamoxifen treatment in postmenopausal breast cancer patients. Clin Cancer Res 15: 3610-3616. Epub 2009 Apr 3628.

32. Sinclair CS, Rowley M, Naderi A, Couch FJ (2003) The 17q23 amplicon and breast cancer. Breast Cancer Res Treat 78: 313-322.

33. Couch FJ, Wang XY, Wu GJ, Qian J, Jenkins RB, James CD (1999) Localization of PS6K to chromosomal region 17q23 and determination of its amplification in breast cancer. Cancer Res 59: 1408-1411.

34. Albertson DG (2006) Gene amplification in cancer. Trends Genet 22: 447-455.

35. Elsheikh S, Green AR, Aleskandarany MA, Grainge M, Paish CE, Lambros MB, ReisFilho JS, Ellis IO (2008) CCND1 amplification and cyclin D1 expression in breast cancer and their relation with proteomic subgroups and patient outcome. Breast Cancer Res Treat 109: 325-335.

36. Letessier A, Sircoulomb F, Ginestier C, Cervera N, Monville F, Gelsi-Boyer V, Esterni B, Geneix J, Finetti P, Zemmour C, Viens P, Charafe-Jauffret E, Jacquemier J, Birnbaum D, Chaffanet M (2006) Frequency, prognostic impact, and subtype association of $8 \mathrm{p} 12,8 \mathrm{q} 24,11 \mathrm{q} 13,12 \mathrm{p} 13,17 \mathrm{q} 12$, and 20q13 amplifications in breast cancers. BMC Cancer 6: 245.

37. Lyzogubov V, Khozhaenko Y, Usenko V, Antonjuk S, Ovcharenko G, Tikhonkova I, Filonenko V (2005) Immunohistochemical analysis of Ki-67, PCNA and S6K1/2 expression in human breast cancer. Exp Oncol 27: 141-144.

38. Phin S, Kupferwasser D, Lam J, Lee-Fruman KK (2003) Mutational analysis of ribosomal S6 kinase 2 shows differential regulation of its kinase activity from that of ribosomal S6 kinase 1. Biochem J 373: 583-591.

39. Massarweh S, Schiff R (2007) Unraveling the mechanisms of endocrine resistance in breast cancer: new therapeutic opportunities. Clin Cancer Res 13: 1950-1954.

40. Yamnik RL, Digilova A, Davis DC, Brodt ZN, Murphy CJ, Holz MK (2009) S6 kinase 1 regulates estrogen receptor alpha in control of breast cancer cell proliferation. J Biol Chem 284: 6361-6369. Epub 2008 Dec 6327.

41. Jiang J, Sarwar N, Peston D, Kulinskaya E, Shousha S, Coombes RC, Ali S (2007) Phosphorylation of estrogen receptor-alpha at Ser167 is indicative of longer diseasefree and overall survival in breast cancer patients. Clin Cancer Res 13: 5769-5776.

42. Yamashita H, Nishio M, Kobayashi S, Ando Y, Sugiura H, Zhang Z, Hamaguchi M, Mita K, Fujii Y, Iwase H (2005) Phosphorylation of estrogen receptor alpha serine 167 is predictive of response to endocrine therapy and increases postrelapse survival in metastatic breast cancer. Breast Cancer Res 7: R753-764. Epub 2005 Jul 2027.

43. Zhou D, Ye JJ, Li Y, Lui K, Chen S (2006) The molecular basis of the interaction between the proline-rich SH3-binding motif of PNRC and estrogen receptor alpha. Nucleic Acids Res 34: 5974-5986.

44. Söderlund K, Perez-Tenorio G, Stål O (2005) Activation of the phosphatidylinositol 3kinase/Akt pathway prevents radiation-induced apoptosis in breast cancer cells. Int $\mathbf{J}$ Oncol 26: 25-32.

45. Liang K, Lu Y, Jin W, Ang KK, Milas L, Fan Z (2003) Sensitization of breast cancer cells to radiation by trastuzumab. Mol Cancer Ther 2: 1113-1120. 
46. Söderlund K, Skoog L, Fornander T, Askmalm MS (2007) The BRCA1/BRCA2/Rad51 complex is a prognostic and predictive factor in early breast cancer. Radiother Oncol 84: 242-251.

47. Russell JS, Brady K, Burgan WE, Cerra MA, Oswald KA, Camphausen K, Tofilon PJ (2003) Gleevec-mediated inhibition of Rad51 expression and enhancement of tumor cell radiosensitivity. Cancer Res 63: 7377-7383.

48. Taki T, Ohnishi T, Yamamoto A, Hiraga S, Arita N, Izumoto S, Hayakawa T, Morita $\mathrm{T}$ (1996) Antisense inhibition of the RAD51 enhances radiosensitivity. Biochem Biophys Res Commun 223: 434-438.

49. Ohnishi T, Taki T, Hiraga S, Arita N, Morita T (1998) In vitro and in vivo potentiation of radiosensitivity of malignant gliomas by antisense inhibition of the RAD51 gene. Biochem Biophys Res Commun 245: 319-324.

50. Stål O, Sullivan S, Wingren S, Skoog L, Rutqvist LE, Carstensen JM, Nordenskjöld B (1995) c-erbB-2 expression and benefit from adjuvant chemotherapy and radiotherapy of breast cancer. Eur J Cancer 31A: 2185-2190.

51. Stål O, Perez-Tenorio G, Åkerberg L, Olsson B, Nordenskjöld B, Skoog L, Rutqvist LE (2003) Akt kinases in breast cancer and the results of adjuvant therapy. Breast Cancer Res 5: R37-44.

52. Gunnarsson C, Ahnström M, Kirschner K, Olsson B, Nordenskjöld B, Rutqvist LE, Skoog L, Stål O (2003) Amplification of HSD17B1 and ERBB2 in primary breast cancer. Oncogene 22: 34-40. 


\section{Supplementary Methods}

Evaluation of S6K1/S6K2 gene copy number using real-time PCR

S6K1 and $S 6 K 2$ gene copy number was assessed in 206 respectively 207 breast tumors using real-time PCR The gene encoding the Amyloid Precursor Protein $(A P P)$ served as endogenous control since no amplifications or deletions have been reported in breast cancer

[1]. Primers and probes were designed using the software Primer Express version 1.5a (Applied Biosystems) and specificity was controlled by blasting to other sequences available at www.ncbi.nlm.nih.gov/BLAST. The APP probe was coupled to the dye FAM and the quencher TAMRA (Sigma-Aldrich) and the $56 K 1 / 2$ MGB probes were attached to FAM and a non-fluorescent quencher (Applied Biosystems). Primers and probes sequences were as follows:

S6K1 Forward: 5'AATATTTATGGAAGACACTGCCTGGTA3'

S6K1 Reverse: 5'TGGCTGCCCATAGTGGGAA3'

S6K1 Probe: 5'TTGTGGTTGCATAGATT3'

S6K2 Forward: 5'ACTGGAGCCTTGTCCTCATTAACT3'

S6K2 Reverse: 5'TCAGTCAGCTCCACCTCTTCATAGT3'

S6K2 Probe: 5'ACAGGCCTACGGACACA3'

APP Forward: 5'TTTGTGTGCTCTCCCAGGTCT3'

APP Reverse: 5'TGGTCACTGGTTGGTTGGC3'

APP Probe 5'CCCTGAACTGCAGATCACCAATGTGGTAG3'

Quantitative real-time PCR was performed with $20 \mathrm{ng}$ DNA in a $15 \mu \mathrm{l}$ reaction mixture, with TaqMan Fast Universal PCR Master Mix 1X final concentration (Applied 
Biosystems) supplemented with $0.1 \mu \mathrm{M}(S 6 K 1)$ or $0.15 \mu \mathrm{M}(S 6 K 2)$ of each primer and probe. The plates were loaded using the liquid handling workstation epMotion 5070 (Eppendorf AG). The absolute quantification assay was performed in the 7500 Fast Real Time PCR system (Applied Biosystems). The thermal cycling conditions were: $95^{\circ} \mathrm{C}$ for $20 \mathrm{~s}$, followed by 40 cycles of $95^{\circ} \mathrm{C}$ for $3 \mathrm{~s}$, and $60^{\circ} \mathrm{C}$ for $30 \mathrm{~s}$. Reactions were analyzed in triplicates using the 7300 Sequence Detection Software version 1.3.1 (Applied Biosystems). A five point's standard curve $(240 \mathrm{ng} / \mu \mathrm{l}-0.94 \mathrm{ng} / \mu \mathrm{l})$ was constructed using fourfold dilutions of DNA from the mammary breast cancer cell line T47D. $S 6 K 1$ and $S 6 K 2$ gene copy number was quantified using the standard curve, and each sample was normalized by calculating the ratio $\mathrm{C}$ (gene)/C $(A P P)$. Cut-off levels for amplification ( $\geq 4$ gene copies) were based on the frequency distribution of the gene copy ratios and were set to $>1.38$ for $S 6 K 1$ and $>2.8$ for $S 6 K 2$. Two gene copies were expected at the modal peak in the frequency distribution, being 0.69 for $S 6 K 1$ and 1.4 for $S 6 K 2$. A cut off for 3 gene copies was defined as 1.04 for $S 6 K 1$ and 2.3 for S6K2. Five non-amplified and five amplified tumors were rerun on five separate occasions to validate the reproducibility of the method. The resultant coefficient of variation was less than $10 \%$ for both genes.

\section{S6K2 mRNA quantification}

mRNA was reverse transcribed into cDNA using the high-capacity cDNA reverse transcription kit (Applied Biosystems), following manufacturer's instructions. For each reaction, $200 \mathrm{ng}$ RNA was added to a final reaction volume of $20 \mu \mathrm{l}$. To confirm that no gDNA was detected, reactions without reverse transcriptase (-RT) were included for five samples. Quantitative fast real time PCR was performed on an ABI Prism 7900ht (Applied 
Biosystems), using the thermal conditions: $95^{\circ} \mathrm{C}$ for $20 \mathrm{~s}$, followed by 40 cycles of $95^{\circ} \mathrm{C}$ for 1 s, and $60^{\circ} \mathrm{C}$ for $20 \mathrm{~s}$. TaqMan assays (Applied Biosystems) for $S 6 K 2$ (Hs00177689_m1) and the endogenous control $A C T B$ (part no 4310881E) were handled according to manufacturer's instructions, using the reaction volume $10 \mu$ l. Relative expression of the gene was calculated with the standard curve method, using SKBR3 cDNA to construct the standard curve. Briefly, all samples were run in triplicates and the median Ct-values were used to calculate a relative expression value $(\mathrm{C})$ for each gene, based on the standard curves. Final mRNA quantitation was performed by calculating the ratio $\mathrm{C}(S 6 K 2) / \mathrm{C}(A C T B)$ for each sample.

\section{Immunohistochemistry}

For staining of S6K2 protein, the tissue microarrays were deparaffinized and rehydrated by several passages in xylen, ethanol and distilled water and the technique proceeded as described before [2] with slight variations. Antigen retrieval was carried out in citrate buffer, $\mathrm{pH}$ 6.0, using a decloaking chamber (BioCare Medical) and the default program $\left(\mathrm{SP} 1=125^{\circ} \mathrm{C}\right.$ for $30 \mathrm{~s}, \mathrm{SP} 2=90^{\circ} \mathrm{C}$ for $10 \mathrm{~s}$, at a pressure of $\left.23-25 \mathrm{psi}\right)$. After $30 \mathrm{~min}$ at room temperature, the samples were incubated with a protein block (Spring Bioscience) for $10 \mathrm{~min}$, followed by $3 \mathrm{~h}$ incubation with a mouse monoclonal antibody against human S6K2 (cat. no MAB2987, R\&D systems) diluted 1:100 in PBS-0.5\% BSA. The anti-mouse Envision+ system conjugated with horse radish peroxidase (Dako) was used as secondary reagent. The color was developed with 3.3-diaminobenzidin hydrochloride (DAB)/ $\mathrm{H}_{2} \mathrm{O}_{2}$ for $10 \mathrm{~min}$ at room temperature, and cell nuclei were counterstained with haematoxilin. All slides were evaluated by two independent observers blinded to the clinical data and the tumors scored 
according to the intensity of nuclear staining (negative or positive) and cytoplasmic staining (negative, weak, moderate or strong).

Cyclin D1 protein expression was assessed using immunohistochemistry as described above, with a few exceptions. For antigen retrieval the slides were boiled in citrate buffer, $\mathrm{pH}$ 6.0, for $12 \mathrm{~min}$ using a pressure cooker, and cooled in room temperature for $30 \mathrm{~min}$. A protein block (Dako) was applied for $10 \mathrm{~min}$ and the slides were incubated with a rabbit polyclonal antibody against Cyclin D1 (Cyclin D1 ab3, Neomarkers, dilution 1:300) at $4{ }^{\circ} \mathrm{C}$ for 21 hours. The secondary antibody (Envision, anti-rabbit, Dako) was applied and visualized according to above. Nuclear staining was evaluated by two observers and graded according to frequency of positive nuclei $(<1 \%, 1-25 \%, 25-75 \%$ or $>75 \%)$.

\section{Immunoblotting}

ZR751, T47D, MCF7 and BT474 cell lysates (30 $\mu \mathrm{g}$ per well) were loaded on a 4-15\% gradient precast gel (Criterion, Bio-Rad). Proteins were transferred to a PVDF membrane, which was blocked with $5 \%$ milk in TBS+0.1\% Tween-20 and probed with the anti-S6K2 antibody $(0.5 \mu \mathrm{g} / \mathrm{ml})$ for incubation overnight at $4^{\circ} \mathrm{C}$. The membranes were incubated with the secondary antibody (polyclonal anti-mouse, Dako, P0447, 1:1000) for one hour at room temperature. Signal was detected with the Amersham ECL Plus detection reagents (GE Healthcare).

1. Bieche I, Olivi M, Champeme MH, Vidaud D, Lidereau R, Vidaud M (1998) Novel approach to quantitative polymerase chain reaction using real-time detection: application to the detection of gene amplification in breast cancer. Int J Cancer 78: 661-666.

2. Jansson A, Delander L, Gunnarsson C, Fornander T, Skoog L, Nordenskjöld B, Stål O (2009) Ratio of 17HSD1 to 17HSD2 protein expression predicts the outcome of tamoxifen treatment in postmenopausal breast cancer patients. Clin Cancer Res 15: 3610-3616. Epub 2009 Apr 3628.

Pérez-Tenorio G, Karlsson E, Marie Ahnström Waltersson M, Olsson B, Holmlund B, Nordenskjöld B, Fornander T, Skoog Land Stål O; Clinical potential of the mTOR targets $S 6 K 1$ and S6K2 in breast cancer

Corresponding author: Olle Stål, Department of Clinical and Experimental Medicine, Division of Surgery and Clinical Oncology, Faculty of Health Sciences, Linköping University, SE-581 85 Linköping, Sweden.

e-mail: olle.stal@liu.se. 
Supplementary Table 1 Cox proportional hazard regression models of local recurrence to test the interaction between $S 6 K 1$ amplification, $17 \mathrm{q}$ amplification, $S 6 K 2$ gain respectively $S 6 K 1$ amplification and/or $S 6 K 2$ gain, and the benefit from radiotherapy

\begin{tabular}{|c|c|c|c|c|}
\hline \multirow{2}{*}{ S6K1 amplification } & \multirow[t]{2}{*}{$\begin{array}{l}\text { No. of } \\
\text { patients }\end{array}$} & \multicolumn{2}{|c|}{$\begin{array}{l}\text { Radiotherapy vs. Chemotherapy } \\
\text { HR }(95 \% \text { CI })\end{array}$} & \multirow[t]{2}{*}{$\begin{array}{l}\text { Test for } \\
\text { interaction }\end{array}$} \\
\hline & & & & \\
\hline - & 184 & $0.27(0.11-0.66)$ & $\mathrm{P}=0.0038$ & \\
\hline+ & 22 & $2.00(0.40-10.0)$ & $\mathrm{P}=0.39$ & $\mathrm{P}=0.035$ \\
\hline $\begin{array}{l}17 \text { q amplification } \\
\text { (S6K1 and/or } H E R 2)\end{array}$ & & & & \\
\hline- & 141 & $0.17(0.05-0.56)$ & $\mathrm{P}=0.0039$ & \\
\hline+ & 57 & $1.30(0.45-3.74)$ & $\mathrm{P}=0.63$ & $\mathrm{P}=0.013$ \\
\hline$S 6 K 2$ gain & & & & \\
\hline - & 163 & $0.41(0.17-0.96)$ & $\mathrm{P}=0.040$ & \\
\hline+ & 44 & $0.30(0.06-1.43)$ & $\mathrm{P}=0.13$ & $\mathrm{P}=0.74$ \\
\hline $\begin{array}{l}S 6 K 1 \text { amplification and/or } \\
S 6 K 2 \text { gain }\end{array}$ & & & & \\
\hline- & 143 & $0.26(0.09-0.77)$ & $\mathrm{P}=0.015$ & \\
\hline+ & 64 & $0.58(0.20-1.70)$ & $\mathrm{P}=0.32$ & $\mathrm{P}=0.29$ \\
\hline
\end{tabular}

Pérez-Tenorio G, Karlsson E, Marie Ahnström Waltersson M, Olsson B, Holmlund B, Nordenskjöld B, Fornander T, Skoog Land Stål O; Clinical potential of the mTOR targets $S 6 K 1$ and S6K2 in breast cancer

Corresponding author: Olle Stål, Department of Clinical and Experimental Medicine, Division of Surgery and Clinical Oncology, Faculty of Health Sciences, Linköping University, SE-581 85 Linköping, Sweden.

e-mail: olle.stal@liu.se. 
$17 q$ positive

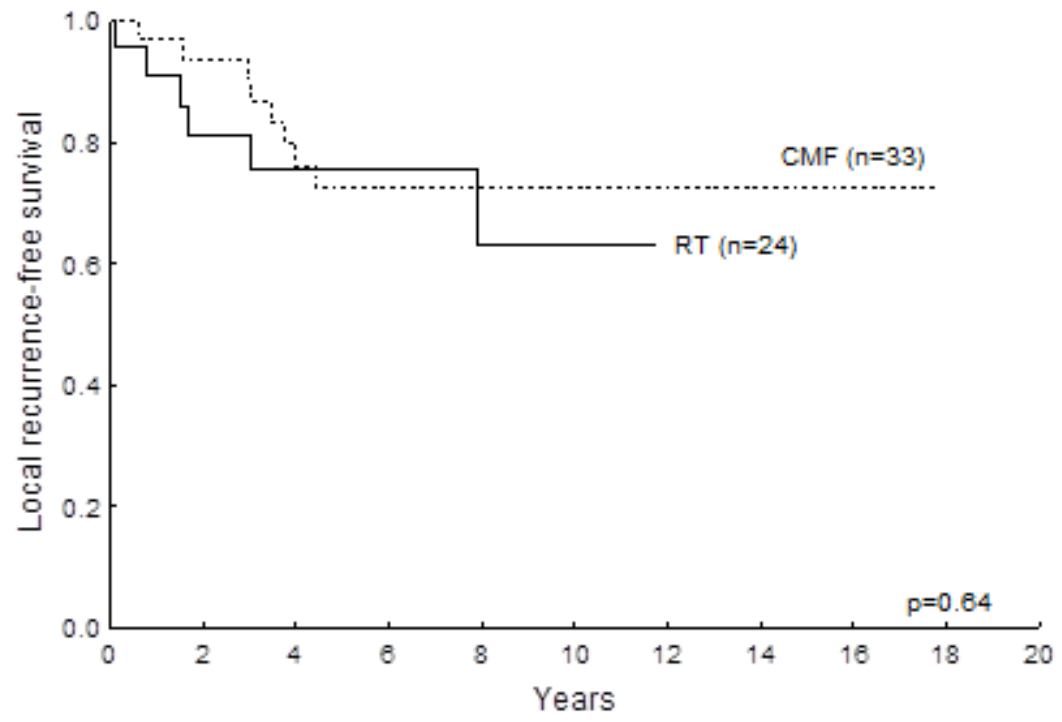

$17 q$ negative

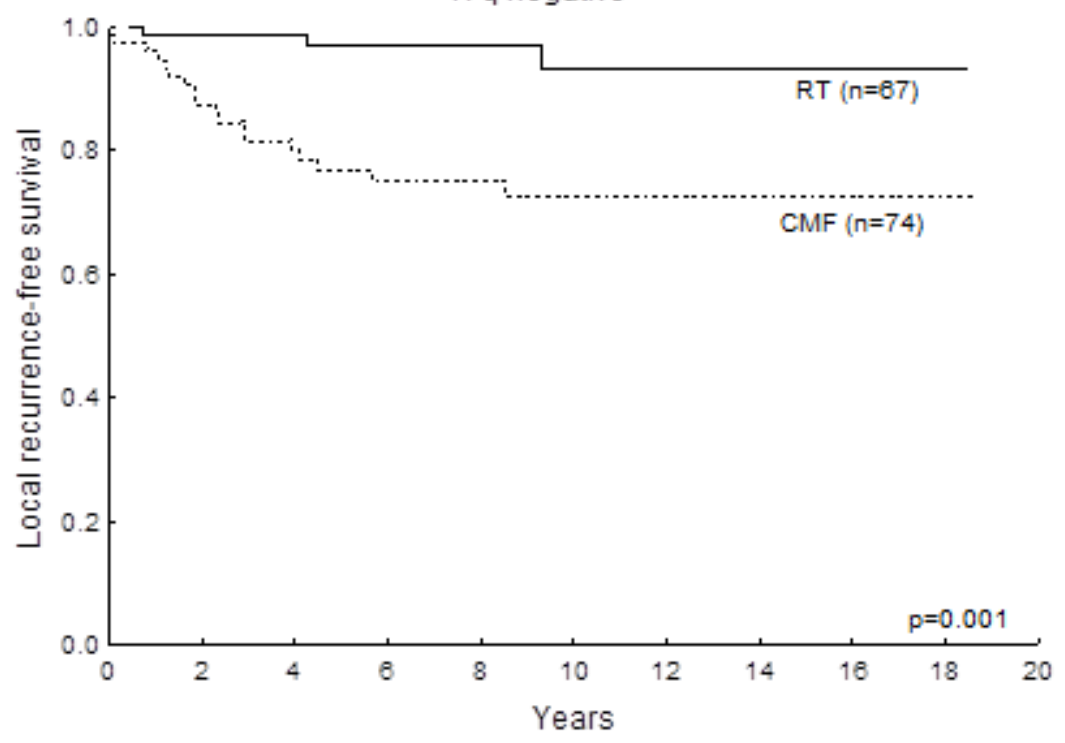

Supplementary Figure 1. Local recurrence-free survival for patients treated with radiotherapy (RT) vs. CMF chemotherapy in relation to $17 \mathrm{q} 21-23$ status: $17 \mathrm{q}$ positive (S6K1 and/or HER $2 \geq 4$ copies) (a); 17q negative (S6K1 and HER2 <4 copies) (b) 